УДК: $372.881 .111 .1 ; 378.147 .31 ; 378.147 .34$

JEL: I21; I25; P46

E. V. Orlova, T. A. Martynova, K. V. Zhukova, A. Yu. Pleshkova

\title{
LANGUAGE AND COMMUNICATION TEACHING AT BUSINESS SCHOOL: NEW PERSPECTIVES
}

St. Petersburg State University, 7/9, Universitetskaya nab., St. Petersburg, 199034, Russian Federation

This paper represents the redesigned language and communication program for bachelor students at the Institute "Graduate School of Management", Saint Petersburg Petersburg University that stemmed from the research of the school stakeholders' needs. The research of the school stakeholders' needs specified the skills that help to formulate new skills agenda. The comparative analysis of learning goals and procedures of two language and communication program types topic-based (previous program type) and skills-based (present program type) - revealed that skills-based type is more advantageous to respond to the students' academic and professional needs as it helps to develop their competencies in a more practical and integrated way. The analysis predetermines the modification of the language and communication program. The paper provides an opportunity to advance the understanding of perspectives in language and communication program development.

Keywords: language and communication program, program development, communication skills in English, topic-based program type, skills-based program type, business education.

\section{ЯЗЫКОВАЯ И КОММУНИКАТИВНАЯ ПРОГРАММА ОБУЧЕНИЯ ДЛЯ БИЗНЕС-ШКОЛ: ПЕРСПЕКТИВЫ РАЗВИТИЯ}

\section{Е. В. Орлова, Т. А. Мартынова, К. В. Жукова, А. Ю. Плешкова}

Санкт-Петербургский государственный университет, Российская Федерация, 199034, Санкт-Петербург, Университетская наб., 7/9

В статье представлена новая учебная языковая и коммуникативная программа для студентов-бакалавров Института «Высшая школа менеджмента» Санкт-Петербургского государственного университета. Программа разработана с учетом результатов исследования потребностей двух групп стейкхолдеров бизнес-школы. Проведенный сравнительный анализ цели и содержания обучения по двум типам языковых и коммуникативных программ - тематико-ориентированной (предыдущий тип программы) и навыко-ориентированной (действующий тип программы) - позволил сделать вывод о том, что второй из них наиболее полно отвечает академическим и карьерным потребностям студентов, способствуя более интегрированному развитию навыков, имеющих практическую направленность. Это предопределило изменение языковой и коммуникативной программы. В статье обсуждаются вопросы реализации и развития разработанной языковой и коммуникативной программы.

Ключевые слова: языковая и коммуникативная программа, разработка программы, коммуникативные навыки на английском языке, тематико-ориентированный тип программы, навыко-ориентированный тип программы, бизнес-образование.

(c) Санкт-Петербургский государственный университет, 2017 


\section{INTRODUCTION}

The process of ongoing changes in educational environments has become intensive in the last decade [Zhukova et al., 2016]. Business schools need to have a clear understanding of the dynamics of the process to be proactive and reactive to changing circumstances.

Previous methods of teaching languages as well as program types are not working successfully and do not stimulate students' academic progress. A modern trend in teaching the English language at business school is to introduce a new balance between language and communication aspects. The increased significance of the communicative component results in the shift from the traditional topic-based teaching approach to a skills-based one.

This paper offers insights into the English language teaching at a particular business school, understanding approaches to program design as a result of multidimensional needs analysis.

The first section of the paper outlines the background of the shift to the new language and communication program for bachelor students at the Institute "Graduate School of Management", Saint Petersburg University (GSOM, SPbU), a theoretical framework for the study, defines the key terms for the research, and provides the comparative analysis of two types of language and communication program. The second section gives an overview of the identified needs and expectations of GSOM corporate partners and bachelor program students revealed through the survey and goes on to discuss the implications how the skills-based program type better meets the needs of two groups of GSOM stakeholders. The remaining part of the paper concludes with the justification of the skills-based program type shift for teaching languages and communication at business school. Finally, areas for further research are identified.

\section{BACKGROUND}

In 2014 the shift to the new 3-year language and communication program for bachelor students at GSOM, SPbU has been shaped by the earlier English language programs for GSOM. There have been identified the key factors that had the main impact on the process of language program development.

Factor 1: The introduction of the new Education Standard in Foreign Language (English). In 1993-2003 the first language program for the Faculty of Management, SPbU, ${ }^{1}$ was designed. It was based on intensive methods to teach English for Specific Purposes (ESP), namely English for business purposes to GSOM, SPbU students.

${ }^{1}$ Faculty of Management, SPbU was established in 1993, it was reorganized into the Graduate School of Management, SPbU in 2006, and it got the new status of the Institute "Graduate School of Management", $\mathrm{SPbU}$ in 2014. 
In 2001 the Foreign Language Department ${ }^{2}$ for the Faculty of Management was established. The principle of language proficiency levels that corresponds with "international certification and international assessment of language competence" was introduced [Grigoryev, Rebikova, 2003]. For the first time the program used the Common European Framework of Reference for Languages (CEFR) terms to define language competence levels [Common European Framework..., 2001].

At that time, the main approach to teaching languages was centered on a foreign language competence development. The level was achieved upon completion of a twoyear General English and one-year Business English courses.

In 2007 GSOM reported the Independent User language proficiency level (B2) as the program learning goal. Teaching English was aimed at developing students' language skills that are sufficient to pass TOEFL with the score no lower than 550 upon completion of the Bachelor Program.

In 2011 Saint Petersburg University introduced SPbU Educational Standard in Foreign Language (English) [Obrazovatel'nyi standart..., 2015]. The B2 level of language competence - CEFR, was announced to be the University graduation requirement. The same year the Department of Foreign Business Languages introduced the new language program that comprised a one-year "General English course", a one-year "Academic English course for managers" and a one-year "Business English course". GSOM students fulfilled the B2 level requirement by the end of their second year of studying English. "The Business English course" for year 3 students was aimed at further development of students' language and communication skills at the B2+ level.

Factor 2: School internationalization. The increased number of GSOM students goes for an exchange semester to study at academic partner business schools. The language program is to be re-focused at developing language and communication skills to be efficient in international academic environment [EFMD Quality Improvement System..., 2016]. The introduction of the new strategy of the Institute "Graduate School of Management" and announcement of modernization and internationalization of academic process its strategic goal coincided with the beginning of the research by the Languages for Academic and Business Communication (LABC) department on language and communication program development for business school.

Factor 3: A higher level of GSOM students' English language proficiency upon enrollment. The more advanced level of language proficiency of GSOM students upon enrollment predetermined new learning goals. Steadily bachelor program students demonstrated a higher level of language and communication skills (table 1). In 2013/14 academic year the ratio of students' English language proficiency at B2 level upon enrollment reached 56,2 percent. It led to the consequent changes in students' needs and expectations in terms of language and communication proficiency. It reinforced the process of re-thinking of the existed approach to teaching and learning.

${ }^{2}$ Foreign Language Department was renamed Languages for Academic and Business Communication department in 2015. 
Table 1. Level of the English language proficiency of GSOM students upon enrollment, 2011/12, 2012/13, and 2013/14 academic years

\begin{tabular}{|c|c|c|c|c|c|c|}
\hline \multirow{2}{*}{$\begin{array}{c}\text { Level of } \\
\text { language } \\
\text { proficiency }\end{array}$} & \multicolumn{2}{|c|}{$2011 / 12$} & \multicolumn{2}{c|}{$2012 / 13$} & \multicolumn{2}{c|}{$2013 / 14$} \\
\cline { 2 - 7 } & $N$ & $R, \%$ & $N$ & $R, \%$ & $N$ & $R, \%$ \\
\hline A2 & 23 & 10,1 & 24 & 10,5 & 17 & 7,2 \\
\hline B1 & 92 & 40,3 & 82 & 35,8 & 86 & 36,6 \\
\hline B2 & 113 & 49,6 & 123 & 53,7 & 132 & 56,2 \\
\hline
\end{tabular}

Note s: $N-$ number of enrolled students; $R$ - ratio of students with a particular language proficiency level out of the total number of enrolled students.

As a result, GSOM Program and Academic Directors articulated new concerns about language and communication programs' outcomes. The majority of students can fulfill standard requirements within one year. There was advanced a need in a new approach to teaching the English language for GSOM students.

Factor 4: Faculty's expectations. GSOM faculty demonstrated higher expectations of students' communication skills in the English language. They reported interest in further cross-discipline collaboration as a prerequisite for their disciplines delivered in English.

Factor 5: GSOM Corporate Partners' expectations. GSOM Corporate Partners provided feedback that facilitated defining new skills agenda aimed at communication quality of GSOM graduates. There emerged new competences that corporate partners require from graduates of GSOM.

Factor 6: New academic debates on language program development for business school. The following issues are in focus.

- How can we address the needs of students who find themselves in multilanguage and multicultural classrooms with the help of a new program design? Teaching English at international business school accounts for an additional responsibility and puts complementary pressure on teachers and educational program designers [Coelho, 2012]. This situation requires not only attention from the academics, but also the actual actions towards sustainable development of the teaching program arrangement.

- What value can we create while teaching English at business schools? It is the time when teaching process transforms into structuring the paths and directions of students' development. Previous methods of teaching languages are not working successfully now and do not stimulate students' academic progress [Orlova, 2015].

- What to teach at business schools - languages or communication? [LouhialaSalminen, Kankaanranta, 2016]. 
- How to become an expert in the sphere of teaching English as a foreign language? [Baschab, Piot, 2005; Greenwood et al., 2007].

Although high quality research works are done regarding management of educational processes [Petrides, Guiney, 2002; Serban, Luan, 2002], only few studies focus on the tactical level of managing some particular subjects [Corbitt, Bradley, Thanasankit, 2005]. In the context of teaching English as a foreign language, there have been few empirical investigations on the aforesaid debatable issues.

The aim of the present paper is to discuss the case of GSOM SPbU language and communication program shift introduced by the Languages for Academic and Business Communication Department for the Graduate School of Management and justify the new design of the language and communication program.

The objectives of the paper are: 1 ) to present the evidence (findings) for the program design shift: the school stakeholders' needs analysis; 2 ) to introduce new skills agenda; 3 ) to present the results of the comparative analysis of learning goals and procedures of two types of language and communication program: topic-based and skills-based; 4) to conclude which language and communication program type meets the needs and expectations of the school's stakeholders.

With the reference to the aim and objectives of the research, the working hypothesis is: why a skills-based program type for language and communication proficiency development is to take the place of the topic-based program type as corresponding to the expectations and needs of the two groups of GSOM stakeholders.

\section{LITERATURE REVIEW}

The competency-based approach to teaching languages [Auerbach, 1986; Mrowicki, 1986; Docking, 1994; Richards, Rodgers, 2003; Nunan, 2007] is central to teaching in Saint Petersburg University [Obrazovatel'nyi standart..., 2015]. A large and growing body of literature has investigated the concepts of "competence" and "competency" which underlay the competency-based approach in language teaching [Chomsky, 1972; Schenck, 1978; Grognet, Crandall, 1982; Docking, 1994; Llurda, 2000; Boyatzis, 2008]. The complexity in modern interpretation of these terms shows the need to clarify what is meant by "competence" and "competency".

A "competence" is defined as a body of knowledge and skills which are developed in the process of learning some subject as well as a person's capability to do something adequately based on the acquired knowledge and skills, whereas a "competency" describes personal attributes that determine a person's capability to apply or use a set of related knowledge and skills [Azimov, Shukin, 2009, p. 107]. Another interpretation of the term 'competency' emphasizes the aspect of purpose in its definition. Thus a competency is a capability to apply the acquired knowledge and skills in order to successfully perform "critical work functions" or tasks in a defined work setting [What is a competency..., 2010]. Basically "competence" and "competency" are interchangeable though competence is more often used to describe a person's general ability, while competency 
is more often used to describe a person's ability to perform a certain task [Competence and competency..., 2017].

This research is based on the concepts of a 'communicative competence', a 'communicative competency' and a "communication skill". A communicative competence is what students know in order to be able to communicate effectively, while a communicative competency stands for the capability of learners to apply knowledge, language and communication skills appropriately for the goal of communication in a particular situation. [Thornbury, 2006, p. 37]. The term "communication skill" is generally understood as "the ability to convey information to another effectively and efficiently in order to be known or understood by others" [Communication skills..., 2017]. In terms of language teaching methods, a communication skill is an acquired way of performing an action based on knowledge and previous experience [Azimov, Shukin, 2009, p. 320].

For this research, a communicative competency refers to the performance: the capability of GSOM students to apply knowledge, language and communication skills, attitudes, and behaviors required for successful performance in academic and professional contexts, while communicative competences refer to the main learning goal and help us determine content organization in a language and communication program.

The researchers [Hutchinson, Waters, 1987; Nunan, 2007; Richards, Rodgers, 2003] point out that a teaching approach significantly determines a program design. Within the framework of the competency-based approach to teaching language and communication, which focuses on students' performance and their demonstration of learning objectives achievement, program designers tend to create a product-oriented type of a program. There have been identified two product-oriented types of a language program: a topic-based type and a skills-based type [Kolesnikova, Dolgina, 2001, p. 224].

In spite of the common learning goal (both program types address students' performance or key competencies that they are to learn and demonstrate), the ways of goal achievement in a topic-based and a skills-based program types are different. It concerns, for example, a course content organization, delivery methods of learning material, evaluation and assessment criteria.

The topic-based program type arranges its content around a set of topics (e.g. work and motivation, company structure, managing across cultures, recruitment). In contrast to a topic-based program type, in a skills-based program type a topic becomes of subordinate importance and the content is built around key competencies which are the main learning goals.

T. Hutchinson and A. Waters point out that the skills-based program type is founded on theoretical and pragmatic principles: "The basic theoretical hypothesis is that underlying any language behavior are certain skills and strategies which the learner uses in order to produce or comprehend discourse... A skills-based type looks at the competence that underlies the performance. A skills-based course, therefore, will present its learning objectives in terms of both performance and competence" [Hutchinson, Waters, 1987, p. 69]. 
The pragmatic principle emphasizes that a skills-based program type also focuses on the process of students' learning enabling them to develop skills and strategies during the course as well as after the course completion.

A skills-based program type has become wide-spread in developing language courses for academic and/or special purposes as this type of program design and implementation gives much freedom in adjusting the program content to the new needs. For this reason a skills-based program type has been chosen as a framework for redesigning and developing of the new language and communication program at the LABC department because it allows aligning the contents of courses to GSOM stakeholders' needs which are constantly updated.

\section{METHODOLOGY}

To identify and specify communication skills for GSOM students we used qualitative research methods: content analysis of language and communication programs, the survey of the two groups of GSOM stakeholders, the comparative analysis of language and communication program types, professional expertise at international conferences, and observation.

To specify the modern approach to the programs design and implementation and better understand the program design phase, the content analysis of language and communication program types [English for Specific Purposes..., 2005; Sloane, Porter, 2009; Basturkmen, 2010; Orlova et al., 2016] was conducted. Traditionally, it has been argued that the process of program design begins with stakeholders' needs investigation and analysis underlying further stages of program design and implementation [Sloane, Porter, 2009; Basturkmen, 2010].

A language and communication program for academic and/or professional purposes is generic by nature and transferable to a variety of specialisms, thus providing a standardized basis for a range of courses and syllabus design [English for Specific Purposes..., 2005]. Furthermore, a program design and its implementation require the identification of program life cycle [Scheirer, 2012] that includes: 1) program design process; 2) program development: pilot implementation; 3) program development: fullscale implementation; 4) program development: continuous full-scale implementation; 5) program evolution phase: evolution onto a new quality.

During the program design process in GSOM the key questions to answer were the following:

- What are the needs identified by the main stakeholders?

- Is a skills-based language and communication program type relevant to stakeholders' needs?

To answer the questions and to specify GSOM SPbU stakeholders' needs, we conducted the needs analysis of the two groups of GSOM stakeholders: GSOM corporate partners and students who participated in an international semester [Orlova et al., 2016]. 
Group 1. Corporate partners. The companies were selected on the basis of their recruitment activity. In 2015 these companies were among the main employers for GSOM graduates. Sixteen corporate partners of GSOM (Appendix) participated in a questionnaire [Questionnaire for the Corporate Partners..., 2015]. It was aimed to get responses to a skill-defining question: what are the language and communication skills that GSOM graduates need to demonstrate at the early career stage? From 36 answers of the corporate partners there have been specified twenty job-related language and communication competences that they expect from GSOM graduates (table 2).

Table 2. Job-related language and communication competences expected from GSOM graduates by corporate partners

\begin{tabular}{|c|c|}
\hline Competences & GSOM graduates are to be able \\
\hline Language & not specified \\
\hline \multirow{20}{*}{ Communication } & $\begin{array}{l}\text { to solve unconventional communication tasks and be ready to do it } \\
\text { autonomously }\end{array}$ \\
\hline & to communicate to senior staff \\
\hline & to deliver the results of the analysis \\
\hline & to see alternative decisions \\
\hline & to respond to provocative questions \\
\hline & to take up responsibility for the results and communicate the responsibility \\
\hline & to network within bigger and smaller professional groups \\
\hline & $\begin{array}{l}\text { to communicate and promote a position even if it contradicts the conventional } \\
\text { way of doing things }\end{array}$ \\
\hline & to request urgent information from colleagues \\
\hline & to use separate data to produce a coherent and reliable argument \\
\hline & to talk shop \\
\hline & to construct a persuasive argument and communicate it \\
\hline & to "read" the interlocutor \\
\hline & to listen to others and be a part of the discussion \\
\hline & $\begin{array}{l}\text { to estimate the risks prone to your business sector and communication risks as } \\
\text { well }\end{array}$ \\
\hline & to communicate in uncertain situations \\
\hline & to deal with fear and anxiety \\
\hline & to communicate in a logical, structural and laconic way \\
\hline & to single out the main idea and deliver its importance to the audience \\
\hline & to be fast in information perception \\
\hline
\end{tabular}


Group 2. Students who participated in an international semester. Sixty bachelor program students of GSOM, who returned from international semester at higher educational institutions, academic partners of GSOM, participated in a questionnaire [Questionnaire for GSOM SPbU students..., 2015-2017]. It was aimed to get responses to three skill-defining questions: 1) What were the communication-related tasks you were to perform? 2) What were the language and communication skills you needed to demonstrate? 3) What were the language and communication skills you had difficulties with?

From the students' responses there have also been specified twenty language and communication skills necessary for academic communication (table 3).

Table 3. Language and communication skills necessary for academic communication by GSOM students

\begin{tabular}{|c|c|}
\hline Competences & GSOM students participating in international semester are to be able \\
\hline \multirow{10}{*}{ Language } & to specify and present the main idea \\
\hline & to speak logically, construct a coherent argument \\
\hline & $\begin{array}{l}\text { to control the quality of speech during long presentation as well as cohesion and } \\
\text { structured thinking }\end{array}$ \\
\hline & to speak impromptu on complicated topics \\
\hline & to use functional grammar to perform in different academic formats \\
\hline & to use academic language \\
\hline & to deliver an exact idea: vocabulary issues \\
\hline & to be used to extensive reading \\
\hline & to write for academic purposes \\
\hline & to make references \\
\hline \multirow{10}{*}{ Communication } & $\begin{array}{l}\text { to perform in the following academic formats: presentations, cases, projects, } \\
\text { essays }\end{array}$ \\
\hline & to speak to big audiences \\
\hline & to communicate in a balanced and calm manner, not to feel anxiety \\
\hline & to find both interesting and valuable information to present and discuss \\
\hline & to keep the audience's attention, keep contact with the audience \\
\hline & to be persuasive and impressive (emotional) \\
\hline & to construct long coherent argument, keep communication under control \\
\hline & to interact, participate in Q and A sessions \\
\hline & to read research articles and participate in the research-related discussions \\
\hline & to structure the information from research articles; to do it fast and proficiently \\
\hline
\end{tabular}

An interesting observation to emerge from the data comparison is that GSOM corporate partners do not distinguish between language and communication competences because language skills are considered to be a means not purpose of business communication, whereas GSOM students have the need to develop their language skills as well as communication competences.

Furthermore the identified evidence suggested the shift to the new language and communication program type and the introduction of the new skills agenda. 


\section{FINDINGS AND DISCUSSION}

Findings from program description analysis. Having reviewed the body of literature on program types and the questionnaire responses, the comparative analysis of a topicbased and a skills-based program types based on the four focuses of program design was conducted (table 4).

Table 4. The comparative analysis of a topic-based and a skills-based program types

\begin{tabular}{|c|c|c|}
\hline \multirow{2}{*}{$\begin{array}{c}\text { Program } \\
\text { design focus }\end{array}$} & \multicolumn{2}{|c|}{ Program design type } \\
\hline & Topic-based & Skills-based \\
\hline $\begin{array}{l}\text { Content } \\
\text { Organization }\end{array}$ & $\begin{array}{l}\text { Subject-specific topics: } \\
\text { human resource } \\
\text { management } \\
\text { culture and change } \\
\text { leadership } \\
\text { strategy and business } \\
\text { environment } \\
\text { marketing } \\
\text { budgets, decisions, risks }\end{array}$ & $\begin{array}{l}\text { Formats of academic and business } \\
\text { communication: } \\
\text { discussion } \\
\text { essay } \\
\text { presentation (academic and business) } \\
\text { research process } \\
\text { project } \\
\text { conference } \\
\text { problem-solving } \\
\text { meeting } \\
\text { negotiation }\end{array}$ \\
\hline $\begin{array}{l}\text { Unit of Content } \\
\text { Organization }\end{array}$ & $\begin{array}{l}\text { Learning situations: } \\
\text { lecture } \\
\text { seminar } \\
\text { essay } \\
\text { presentation (academic and } \\
\text { business) } \\
\text { meeting }\end{array}$ & $\begin{array}{l}\text { Subject-specific topics: } \\
\text { human resource management } \\
\text { culture and change } \\
\text { leadership } \\
\text { strategy and business environment } \\
\text { marketing } \\
\text { budgets, decisions, risks }\end{array}$ \\
\hline $\begin{array}{l}\text { Language and } \\
\text { communicative } \\
\text { skills }\end{array}$ & $\begin{array}{l}\text { Listening, speaking, reading, and } \\
\text { writing to complete academic } \\
\text { and professional topic-related } \\
\text { tasks }\end{array}$ & $\begin{array}{l}\text { Integrated language, communicative and } \\
\text { study skills to perform in academic and } \\
\text { business formats }\end{array}$ \\
\hline \multirow{3}{*}{ Assessment } & $\begin{array}{l}\text { Communicative task } \\
\text { achievement in academic/ } \\
\text { business learning situations }\end{array}$ & $\begin{array}{l}\text { Communicative task achievement in } \\
\text { academic/business formats }\end{array}$ \\
\hline & $\begin{array}{l}\text { Language and communicative } \\
\text { skills: listening, speaking, } \\
\text { reading and writing needed } \\
\text { to complete academic and } \\
\text { professional topic-related tasks }\end{array}$ & $\begin{array}{l}\text { Integrated language, communicative and } \\
\text { study skills needed to perform in academic/ } \\
\text { business formats }\end{array}$ \\
\hline & $\begin{array}{l}\text { Language skills (vocabulary, } \\
\text { grammar, pronunciation) }\end{array}$ & $\begin{array}{l}\text { Functional language skills needed to } \\
\text { communicate in academic/business formats } \\
\text { (vocabulary, grammar, pronunciation) }\end{array}$ \\
\hline
\end{tabular}


The analysis of program types proved a skills-based type to be more advantageous to respond to GSOM students' academic and professional needs as it helps to develop their competences in a more practical and integrated way.

Findings from the empirical surveys. The study of the questionnaires' responses has helped to formulate competences relevant to the language and communication program for bachelor students GSOM. The job-related competences identified by GSOM corporate partners (expectations to GSOM graduates' language and communication skills) have been reformulated into language and communication program competences. The example of the competence reformulation ( 7 out of 20 ) is presented in figure 1.

\begin{tabular}{|c|c|}
\hline Corporate Partners & Language and Communication Program \\
\hline GSOM graduates are to be able: & $\begin{array}{l}\text { Students can use language means and } \\
\text { communication strategies: }\end{array}$ \\
\hline to communicate to senior staff & as response to status, register, and other issues \\
\hline to deliver the results of the analysis & to communicate the results of the analysis \\
\hline to see alternative decisions & $\begin{array}{l}\text { to specify and communicate alternatives (functional } \\
\text { language) }\end{array}$ \\
\hline to respond to provocative questions & to deal with aggressive audiences \\
\hline $\begin{array}{l}\text { to network within bigger and smaller } \\
\text { professional groups }\end{array}$ & to socialize with different audiences \\
\hline $\begin{array}{l}\text { to communicate and promote a } \\
\text { position even if it contradicts the } \\
\text { conventional way of doing things }\end{array}$ & to introduce conflicting ideas \\
\hline $\begin{array}{l}\text { to request urgent information from } \\
\text { colleagues }\end{array}$ & $\begin{array}{l}\text { to request information (both in oral and written } \\
\text { forms) }\end{array}$ \\
\hline
\end{tabular}

Figure 1. Job-related competences identified by GSOM corporate partners and competences for the language and communication program skills agenda

The competences identified by the corporate partners (table 2) and GSOM students after international semester (table 3 ) have helped to identify a new competences agenda for the language and communication program and specify the particular courses within the program: "Academic communication skills in English", "Academic communication skills in English: subject-specific", and "Business communication skills in English". Based on the competences' analysis, we have allocated the identified skills throughout the courses within the three-year program that intend the stages of introduction, development and/ or mastering these competences.

New competences to be introduced developed or mastered during the program implementation as response to corporate partners' expectations are presented in figure 2 . 


\begin{tabular}{|c|c|c|c|}
\hline $\begin{array}{l}\text { Students can use } \\
\text { English language } \\
\text { means and } \\
\text { communication } \\
\text { strategies }\end{array}$ & $\begin{array}{r}\text { Year 1. } \\
\text { Academic } \\
\text { communication } \\
\text { skills in English }\end{array}$ & $\begin{array}{r}\text { Year 2. } \\
\text { Academic } \\
\text { communication } \\
\text { skills in English: } \\
\text { subject-specific }\end{array}$ & $\begin{array}{r}\text { Year 3. } \\
\text { Business } \\
\text { communication } \\
\text { skills in English }\end{array}$ \\
\hline $\begin{array}{l}\text { to demonstrate active } \\
\text { listening techniques } \\
\text { when participating in } \\
\text { discussions }\end{array}$ & * & $* *$ & $* * *$ \\
\hline $\begin{array}{l}\text { to produce a coherent and } \\
\text { reliable argument from } \\
\text { different information } \\
\text { sources }\end{array}$ & & * & $* *$ \\
\hline $\begin{array}{l}\text { to request information } \\
\text { (both in oral and written } \\
\text { forms) }\end{array}$ & & $*$ & $* *$ \\
\hline $\begin{array}{l}\text { to communicate the } \\
\text { results of the analysis }\end{array}$ & $*$ & $* *$ & $* *$ \\
\hline $\begin{array}{l}\text { to deal with aggressive } \\
\text { audiences }\end{array}$ & $*$ & $* *$ & $* *$ \\
\hline $\begin{array}{l}\text { when socializing with } \\
\text { different audiences }\end{array}$ & & $*$ & $* *$ \\
\hline $\begin{array}{l}\text { to specify and } \\
\text { communicate alternatives } \\
\text { (functional language) }\end{array}$ & & $*$ & $* *$ \\
\hline $\begin{array}{l}\text { to introduce conflicting } \\
\text { ideas }\end{array}$ & * & $* *$ & $* *$ \\
\hline to communicate status & & * & * \\
\hline $\begin{array}{l}\text { to communicate the idea } \\
\text { of responsibility }\end{array}$ & & * & * \\
\hline $\begin{array}{l}\text { to specify an } \\
\text { unconventional } \\
\text { communication task and } \\
\text { respond to it }\end{array}$ & & & $*$ \\
\hline $\begin{array}{l}\text { to communicate in } \\
\text { uncertain situations }\end{array}$ & & & * \\
\hline $\begin{array}{l}\text { to communicate the } \\
\text { "risky" issues }\end{array}$ & & & $*$ \\
\hline $\begin{array}{l}\text { to deal with public } \\
\text { speaking fear and anxiety }\end{array}$ & & * & $* *$ \\
\hline
\end{tabular}

Figure 2. New competences agenda to be included into the language and communication program skills agenda as response to corporate partners' expectations

Note $s:{ }^{*}$ - introduction, ${ }^{* *}-$ development, ${ }^{* *}$ - mastering. 
New competences to be introduced developed or mastered during the program implementation as response to GSOM students' expectations are presented in figure 3.

\begin{tabular}{|c|c|c|c|}
\hline $\begin{array}{l}\text { Students can use } \\
\text { English language } \\
\text { means and } \\
\text { communication } \\
\text { strategies }\end{array}$ & $\begin{array}{r}\text { Year 1. } \\
\text { Academic } \\
\text { communication } \\
\text { skills in English }\end{array}$ & $\begin{array}{r}\text { Year 2. } \\
\text { Academic } \\
\text { communication } \\
\text { skills in English: } \\
\text { subject-specific }\end{array}$ & $\begin{array}{r}\text { Year 3. } \\
\text { Business } \\
\text { communication } \\
\text { skills in English }\end{array}$ \\
\hline $\begin{array}{l}\text { to construct long } \\
\text { coherent argument, keep } \\
\text { communication under } \\
\text { control }\end{array}$ & * & $* *$ & $* *$ \\
\hline $\begin{array}{l}\text { to read research articles } \\
\text { and participate in } \\
\text { the research-related } \\
\text { discussions }\end{array}$ & * & $* *$ & \\
\hline $\begin{array}{l}\text { to structure the } \\
\text { information from } \\
\text { research articles. } \\
\text { To do it fast and } \\
\text { proficiently }\end{array}$ & * & $* *$ & \\
\hline to speak to big audiences & & * & * \\
\hline $\begin{array}{l}\text { to control the quality } \\
\text { of speech during a long } \\
\text { presentation as well as } \\
\text { cohesion and structured } \\
\text { thinking }\end{array}$ & & * & $* *$ \\
\hline $\begin{array}{l}\text { to communicate in } \\
\text { a balanced and calm } \\
\text { manner, not to feel } \\
\text { anxiety }\end{array}$ & * & $* *$ & $* *$ \\
\hline $\begin{array}{l}\text { to speak impromptu on } \\
\text { complicated topics }\end{array}$ & * & $* *$ & $* * *$ \\
\hline
\end{tabular}

Figure 3. New competences agenda to be included into the language and communication program skills agenda as response to GSOM students' expectations

Not e s: ${ }^{*}$ - introduction, ${ }^{* *}-$ development, ${ }^{* *}$ - mastering. 
Questionnaire responses and direct observation (thesis defenses, interactive tasks completion) have helped to identify a new communication gap: students have difficulties with getting out of stressful situations in order to be safe from damaging their reputation. Hence a new skills agenda has emerged (figure 4).

\begin{tabular}{|l|r|r|r|}
\hline $\begin{array}{l}\text { Students can use } \\
\text { English language } \\
\text { means and } \\
\text { communication } \\
\text { strategies }\end{array}$ & $\begin{array}{r}\text { Year 1. } \\
\text { Academic } \\
\text { communication } \\
\text { skills in English }\end{array}$ & $\begin{array}{r}\text { Year 2. } \\
\text { communication } \\
\text { skills in English: } \\
\text { subject-specific }\end{array}$ & $\begin{array}{r}\text { Year 3. } \\
\text { Business } \\
\text { communication } \\
\text { skills in English }\end{array}$ \\
\hline $\begin{array}{l}\text { to reinforce positive } \\
\text { relationships }\end{array}$ & $\star$ & $* *$ & $\star *$ \\
\hline $\begin{array}{l}\text { to have valuable impact } \\
\text { on their interlocutors }\end{array}$ & $*$ & $\star *$ & $\star * *$ \\
\hline $\begin{array}{l}\text { to help their } \\
\text { interlocutors to meet } \\
\text { their potential }\end{array}$ & $\star$ & $*$ & $\star *$ \\
\hline
\end{tabular}

Figure 4. Three new skills to develop to be introduced into the language and communication program

No t e $:^{*}$ - introduction, ${ }^{* *}$ - development, ${ }^{* *}$ - mastering.

This combination of findings has important implications for developing a new skills-based program type as it provides possibilities to respond to the current needs and expectations of GSOM stakeholders. These findings also imply that communication skills can be developed gradually and consistently from Year 1, from the level of introducing communication skills to students, to Year 3 when students are expected to develop and/or master the communication skills which they have started to learn. This interrelated way of developing skills may help students to become more efficient communicators.

The research outcomes were introduced to various professional communities at the international conferences to initiate the further discussion and specify the limitations of the present stage of the program implementation: the international research conference "GSOM Emerging Markets Conference 2015 and 2016" (St. Petersburg, Russia) and international symposium "Language, Communication \& Management Education" 2017, section "Innovation in Theory and Practice", Stockholm School of Economics (Stockholm, Sweden).

The main limitation of the present research is the early stage of the program implementation. The pilot stage has only introduced the initial data to make 
conclusions for the program evaluation and adaptation. Further evidence collected during the program implementation stage is needed to answer the question whether the program is implemented as intended. The forthcoming full-scale program implementation is required to assess the efficacy of the skills-based language and communication program type.

\section{CONCLUSION}

In Graduate School of Management, St. Petersburg University students' ability to communicate in different languages is one of the imperative goals of the academic process. In 2014 the Languages for Academic and Business Communication Department designed a new three-year language and communication program for GSOM bachelor students. For the last three years the faculty have been involved into discussion to answer the question: what are the most important prerequisites and indicators of success for language and communication programs at business schools. The main participants of the discussion are students, language and other subject teachers, academic directors and corporate partners.

This study has shown that the skills-based language and communication program type better meets the revealed needs and expectations of GSOM stakeholders. A skillsbased program type is an open responsive framework which permits to fill it in with new sets of language and communication skills on agenda that can be identified during further research.

Forthcoming research should focus on the indicators of the program effectiveness and research methods to evaluate the effectiveness of the program implementation.

\section{References}

Azimov E. G., Shukin A. N. 2009. Novyy slovar metodicheskikh terminov i ponyatiy [New Dictionary of Methodological Terms and Concepts]. Moscow: IKAR. (In Russian)

Kolesnikova I., Dolgina O. 2001. Anglo-Russkiy terminologicheskiy spravochnik po metodike prepodavaniya inostrannykh yazykov [A Handbook of English-Russian Terminology for Language Teaching]. St. Petersburg: Russian-Baltic information center "Blitz". (In Russian)

Obrazovatel'nyi standart Sankt-Peterburgskogo gosudarstvennogo universiteta po urovniu vysshego obrazovaniia "bakalavriat". Prikaz ot 19 marta 2015 g. N 1585/1 [Educational Standard of Higher Education of St. Petersburg State University: Bachelor Program. Order 1585/1. 2015]. URL: http://spbu.ru/images/orders/2015/1585_1.pdf (accessed: 10.11.2016).

Auerbach E. R. 1986. Competency-based ESL: One step forward or two steps back? TESOL Quarterly 20 (3): 411-415.

Baschab J., Piot J. 2005. The Professional Services Firm Bible. Hoboken, NJ: John Wiley and Sons.

Basturkmen H. 2010. Developing Courses in English for Specific Purposes. London: Palgrave MacMillan.

Boyatzis R. E. 2008. Competencies in the 21st century. Journal of Management Development 27 (1): 5-12.

Chomsky H. 1972. Language and Mind. New York: Harcourt Brace Jovanovich.

Coelho E. 2012. Language and Learning in Multilingual Classrooms: A Practical Approach. Bristol: Multilingual Matters. 
Common European Framework of Reference for Languages: Learning, Teaching, Assessment (CEFR). Council of Europe. 2001. Cambridge: Cambridge University Press. URL: https://rm.coe. int/1680459f97 (accessed: 15.11.2016).

Communication skills. Business Dictionary. 2017. URL: http://www.businessdictionary.com/definition/communication-skills.html (accessed: 16.01.2017).

Competence and competency. Grammarist. 2017. URL: http://grammarist.com/words/competenceand-competency/ (accessed: 14.01.2017).

Corbitt B., Bradley T., Thanasankit T. 2005. Factors influencing the implementation and use of a portal for knowledge management in higher education. Proceedings of the 9th Pacific Asia Conference on Information Systems. Bangkok, Thailand; 1-12.

Docking R. 1994. Competency-based curricula - the big picture. Prospect 9 (2): 11-15.

EFMD Quality Improvement System. The EFMD Accreditation for International Business Schools. 2016 EQUIS Standards and Criteria. 2016 URL: https://www.efmd.org/images/stories/efmd/EQUIS/ 2016/EQUIS_Standards_and_Criteria.pdf (accessed: 10.11.2016).

English for Specific Purposes (ESP). National Curriculum for Universities. 2005. Kyiv: British Council.

Greenwood R., Li S. X., Prakash R., Deephouse D. L. 2007. Reputation, diversification and organizational explanations of performance in professional service firms. Organization Science 16 (6): 661-673.

Grigoryev I. V., Rebikova L. D. 2003. English Language Program for the Faculty of Management. St. Petersburg: St. Petersburg State University.

Grognet A., Crandall J. 1982. Competency based curricula in adult ESL. ERIC/CLL News Bulletin (6): 3-4.

Hutchinson T., Waters A. 1987. English for Specific Purposes. A Learning-Centered Approach. Cambridge: Cambridge University Press.

Llurda E. 2000. On competence, proficiency, and communicative language ability. International Journal of Applied Linguistics 10 (1): 85-96.

Louhiala-Salminen L., Kankaanranta A. 2016. Teaching language or teaching communication? Experiences and insights from the curriculum of an international business school. Conference proceedings GSOM Emerging Markets Conference. 6-8 October, St. Petersburg, GSOM; 239-241. URL: http:// gsom.spbu.ru/files/a_1/abstract_s_book_gsom_em_conference_2016.pdf (accessed: 10.12.2016).

Mrowicki L. 1986. Project Work English Competency-Based Curriculum. Portland, OR: Northwest Educational Cooperative.

Nunan D. 2007. Standard-based approaches to the evaluation of ESL instruction. In: J. Cummins, C. Davison (eds.). International Handbook of English Language Teaching. New York: Springer; 421-438.

Orlova E. V. 2015. Efficient communication for research: Newest trends in designing English language and communication courses for graduate students. Humanities and Science University Journal: Art History, Philology and Historical Sciences (12): 171-180. URL: http://en.unipress.pro/catalog. php?pid=83 (accessed: 10.12.2016).

Orlova E. V., Martynova T. A., Goman Yu. V., Zarutckaia E. V., Rybina T. N. 2016. Communication skills acquisition at business school: academic and professional needs analysis for communication skills programmes development. Philological Sciences. Issues of Theory and Practice 5 (1): 197-206.

Petrides L., Guiney S. 2002. Knowledge management for school leaders: an ecological framework for thinking schools. Teachers College Record 104 (8): 1702-1717.

Questionnaire for GSOM SPbU students, international semester participants. 2015-2017. Anketolog.ru. URL: https://anketolog.ru/report/answer/list/131025?token=soqiIJtlD9 (accessed: 05.11.2016).

Questionnaire for the corporate partners of GSOM SPbU. 2015. Anketolog.ru. URL: https://anketolog. ru/survey/manage/info/129544 (accessed: 05.11.2016). 
Richards J., Rodgers Th. 2003. Approaches and Methods in Language Teaching. Cambridge: Cambridge University Press.

Scheirer M. A. 2012. Planning evaluation through the program life cycle. American Journal of Evaluation 33 (2): 263-294.

Schenck E. 1978. A Guide to Identify a High School Graduation Competencies. Portland, OR: Northwest Regional Education Laboratory.

Serban A., Luan J. 2002. Knowledge Management: Building a Competitive Advantage in Higher Education: New Directions for Institutional Research. San Francisco, CA: Jossey-Bass.

Sloane D., Porter E. 2009. Contextualising, Embedding and Mapping (CEM): A model and framework for rethinking the design and delivery of an in-sessional academic literacy programme support. EMERGE. (1): 1-15. URL: http://nrl.northumbria.ac.uk/9984/1/Sloan_and_Porter_Emerge_ Iss1.pdf (accessed: 05.11.2016).

Thornbury S. 2006. An A-Z of ELT: A Dictionary of Terms and Concepts Used in English Language Teaching. Oxford, UK: Macmillan Education.

What is a competency? 2010. University of Texas Health School. URL: https://sph.uth.edu/content/ uploads/2012/01/Competencies-and-Learning-Objectives.pdf (accessed: 12.12.2016).

Zhukova K., Pleshkova A., Mihnevich A., Pehtin I. 2016. One approach to administrative and educational processes modeling: case of bachelor program. International Journal of Education and Social Science 3 (3): 58-66.

For citation: Orlova E. V., Martynova T. A., Zhukova K. V., Pleshkova A. Yu. 2017. Language and communication teaching at business school: New perspectives. Vestnik of Saint Petersburg University. Management, 2017, vol. 16, issue 2, pp. 322-339. DOI: 10.21638/11701/spbu08.2017.206.

Статья поступила в редакцию 20 декабря 2016 г.; принята к печати 19 апреля 2017 г.

Контактн а информация

Орлова Елена Владимировна - кандидат психологических наук, доцент; orlova@gsom.pu.ru

Мартынова Татьяна Александровна - кандидат педагогических наук, доцент; martinova@gsom.pu.ru

Жукова Киран Витальевна - кандидат технических наук, доцент; k.v.zhukova@gsom.pu.ru

Плешкова Анастасия Юрьевна - аспирант; pleshkova@gsom.pu.ru

Orlova Elena V. — PhD, Associate Professor; orlova@gsom.pu.ru

Martynova Tatyana A. - PhD, Associate Professor; martinova@gsom.pu.ru

Zhukova Kiran V. — PhD, Associate Professor; k.v.zhukova@gsom.pu.ru

Pleshkova Anastasiia Yu. _ PhD student; pleshkova@gsom.pu.ru 
Appendix

The list of GSOM SPbU corporate partners participated in the questionnaire

\begin{tabular}{|l|c|}
\hline \multicolumn{1}{|c|}{ Company } & Number of responses \\
\hline A. T. Kearney & 1 \\
\hline ALT Research \& Consulting & 1 \\
\hline Baltika Breweries & 1 \\
\hline Citibank & 1 \\
\hline Coca-Cola Hellenic & 1 \\
\hline EMC & 1 \\
\hline Gazprom Export LLC & 1 \\
\hline Heineken & 11 \\
\hline IBM East Europe/Asia & 10 \\
\hline JTI Пeтpo & 1 \\
\hline LVMH P\&C & 1 \\
\hline Metro Cash \& Carry & 1 \\
\hline Russian Railways & 1 \\
\hline St. Petersburg Technopark OJSC & 1 \\
\hline The Boston Consulting Group & 1 \\
\hline Unilever & 1 \\
\hline Total & 1 \\
\hline
\end{tabular}

